\title{
Sexual Harassment in Egypt: An Old Plague in a New Revolutionary Order
}

\section{Zusammenfassung \\ Sexuelle Belästigung in Ägypten: eine alte Plage in einer neuen revolutionären Ordnung \\ Der Beitrag analysiert das Phänomen der se- xuellen Belästigung in Ägypten in einem sich kontinuierlich wandelnden soziopolitischen Kontext und argumentiert, dass zu einer um- fassenden Analyse der ägyptischen Revolu- tion zwingend auch ein Verständnis für den breiteren soziopolitischen Kontext notwen- dig ist, der seit dem 19. Jahrhundert zu ei- ner Kultur der Frauenfeindlichkeit und sexu- eller Gewalt beigetragen hat. Sexuelle Belä- stigung tritt in unterschiedlichen Formen auf und sexuelle Gewalt wird in verschiedener In- tensität ausgeübt, auch sind die Gründe, in denen sie wurzeln, im Verlauf der Geschichte nicht immer dieselben. Basierend auf Archiv- recherche, persönlicher Beobachtung und In- terviews mit Aktivistinnen wird gezeigt, wie sich sexuelle Belästigung verstärkt und in Ge- walt gewandelt hat und wie dies durch den harten Kurs der staatlichen Sicherheitspoli- tik und neoliberalen Maßnahmen verursacht wurde. \\ Schlüsse/wörter \\ Tahrir, Ägypten, sexuelle Gewalt, Körper, Frauenbewegung, Revolution}

\section{Summary}

The article aims at analyzing sexual harassment in Egypt in changing sociopolitical contexts at various times; I argue that no analysis of the Egyptian revolution is complete without an understanding of these broad sociopolitical conditions that have contributed to the culture of anti-women and sexual violence since the 19th century. I am not suggesting that sexual harassment always took the same form and was practiced with the same level of violence, or even rooted in the same reason(s) throughout that long period of history. Based on archival research, personal observations and intensive interviews with activists I show how sexual harassment increased in violence caused by the state's heavy-handed security and neoliberal policies.

\section{Keywords}

Tahrir, Egypt, sexual violence, body, women's movement, revolution 


\section{Introduction ${ }^{1}$}

Since the Tahrir Revolution broke out in Egypt in January 2011, revolutionary and counter-revolutionary forces have turned the female body into a site for political struggles and both sides have politicized sexual harassment against women. Continuously destabilized Egyptian regimes have employed sexual harassment to drive female protestors out of the public space, while oppositional activists have put the issue at the top of their political agendas in order to embarrass the regime and mobilize followers to protest. Both camps have mistakenly discussed sexual harassment as if it were "a new phenomenon" that came about as a result of the recent increase in women's political participation.

In the first part of this article I trace sexual harassment in Egyptian urban spaces back to the late 19th century. I show how nationalists used it in debates to express socio-political anxiety about the British occupation (1882-1954) and rapid urbanization during the 20th century. These debates ignored women's need for legal protection in the public space and implicitly denied women's right to the public space. I then discuss how the state and oppositional activists politicized the female body against the backdrop of the revolutionary movements in the first decade of the 21 st century. I argue that the ongoing struggles over the last decade have succeeded in destabilizing the gender and sexual orders and have put women's rights to control their own bodies and sexuality at the top of the national political agendas. While indicating that sexual harassment has been a constant in the Egyptian public space since the second half of the 19th century I am by no means suggesting that sexual harassment took the same form, was practiced in connection with the same level of violence, or even rooted in the same reason(s) throughout that long period of history.

The article aims at analyzing sexual harassment in continuingly changing sociopolitical contexts and argues that no analysis of the Egyptian revolution is complete without an understanding of the broad sociopolitical contexts that contributed to the anti-women and sexual violence culture.

\section{Sexual Harassment in Egypt: A History}

Sexual harassment, or taharush jinsi in Arabic, is a relatively new term that was introduced to everyday Egyptian as late as the 1990s when civil society organizations started paying attention to how widespread gender-based violence was. Until recently, Egyptian penal codes, abundant with articles dealing with rape and sexual honor code violations, were devoid of articles that explicitly came out in favor of punishing harassment. Meanwhile, the popular concept of $m u$ 'aksa, often translated as "teasing”" in colloquial Egyp-

$1 \quad$ This article started in 2013 as a public talk in Illinois State University-Normal. I'd like to thank Professor Issam Nassar for encouraging me to think about sexual harassment in a historical perspective. I presented a draft of this paper at Oregon State University in 2014. I am grateful to Professor Bradley Boovy and all colleagues at Women, Gender and Sexuality Studies at OSU for their comments and feedback. My thanks also go to many Egyptians who shared their experiences and thought. I am grateful particularly to activists and friends Dalia Abd Elhameed, Thoraya Abd al-Radi and Hala 'Uthman who sharpened my observations and challenged my assumptions. Finally, this article is dedicated to all victims and survivors of sexual violence in Egypt and beyond. 
tian, conflated sexual harassment in public spaces with flirtation. That conceptualization contributed to the acceptance of the widespread harassment of women in public, and not many people saw it as a crime or a violation until a decade ago.

The case of Nuha Rushdi, a young woman who pressed charges against a car driver who violently groped her in a Cairo street in 2008, exposed the legal void. When Egyptian bloggers exposed mob harassment on public holidays, those who acknowledged the phenomenon debated the issue as a recent violation of Egyptian traditions and morality. There is strong evidence to suggest that sexual harassment - as a form of sexual and gender-based violence - has a long and deep history in Egyptian public spaces. The popular press in the 19th century hosted debates among male Egyptians with different sociopolitical backgrounds on the issue under the heading of "public morality" (al-adab al- 'amma). Male essayists and commentators warned about youth who harassed women in the streets and on public transport in clear violation of public decency and traditions (Al-Muqattam 1898; al-Nadim A. 1892a; al-Nadim A. 1892b; al-Mu'ayyid 1908). Observing urban life in Alexandria in the 1870s, the nationalist Abdullah al-Nadim (1842-1896) described men who were staring at women riding carriages as villainous and vicious ('Itman 1995: 149). Fifteen years later, al-Nadim depicted Cairo streets as dangerous places for women. He used his social satirical magazine al-Ustadh to voice anger about men who rubbed their bodies against women and shamelessly stood pushing themselves against women's backs even in sacred places, such as near the al-Sayyida Zaynab Shrine (al-Nadim A. A. 1892: 395-9).

Against the backdrop of Egypt's defeat by the British forces that brought the county under British occupation in 1882 (and lasted until 1954), male Egyptian commentators used the nation's frustration and disorientation to blame women for the nation's decline and deterioration. All those who discussed sexual harassment attributed it to women's inappropriate dress and ill-mannered behavior in public (Al-Mu'ayyd 1906). That contradicted the reality in which men did not spare veiled women from harassment. By the turn of the century, Muhammad Rashid Rida (1865-1935) reported in his al-Manar magazine that men made advances towards veiled women in the streets "as if [these women] were their legitimate wife," and he urged Cairo police to arrest those who solicited women in streets to commit adultery (Rida 1900). Schoolgirls in uniform faced verbal harassment by afandiyya, educated males in Western clothing. Afandiyya approached girls on their way between home and school and whispered obscene, shameful wards (al-Manfaluti 1984: 606-612; Rida 1900). In the same way as the harassed women varied in age, class, and level of modesty, so the harassers also came from all walks of life, including old and religious men, as Germanyus's cartoon published in 1908 (see Fig. 1) shows. The editor of the al-Muqattam newspaper was appalled that men, some with grey hair, roamed the streets and rode trams following any woman who was out walking without a man, blocked women's path and whispered obscene words and exposed pornographic images, then laughed at their trembling female victim (Al-Muqattam 1898).

These writings not only address the phenomenon of sexual harassment, they also speak of the anxiety about women's presence in urban spaces in times of rapid social change, of European political and economic domination, and of British occupation and westernization (Hammad 2014). Since the late 19th century, Egyptian urban spaces have been continually expanding and the urban population has continually increased. Inte- 


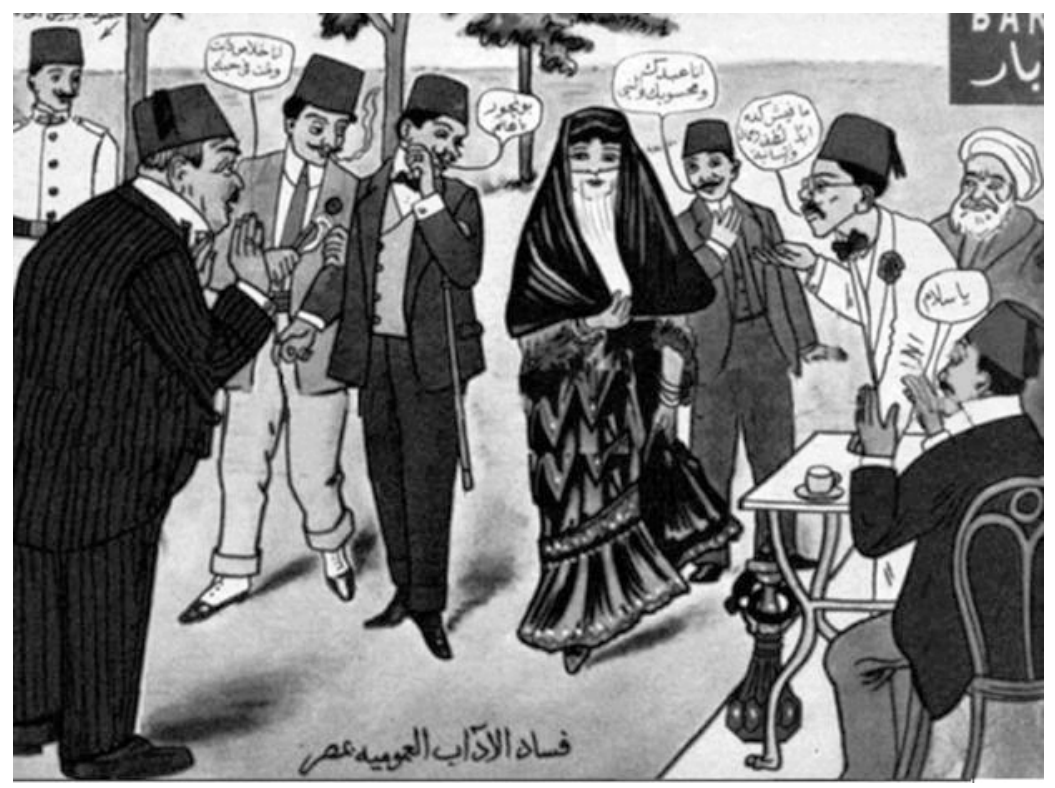

Fig. 1: Men from all sociocultural backgrounds verbally harassing a veiled woman while a policeman looks on.

gration into the global economy, conscription, and a modern education system have brought about changes in Egyptian households, and women have become increasingly more visible in public spaces as working women and students (Kozma 2011: 96). Egypt witnessed a rapid industrialization drive throughout the 20th century. The unequal development of urban towns that housed modern government institutions, factories, and schools contributed to the expansion of the urban space and attracted the rural population to work and live in towns and cities. Modern transportation provided greater mobility than had ever previously been imagined. Lower-class women were recruited from towns and villages to work in factories and more girls and women enrolled in schools. Educated women flooded the job market in both the public and private sectors; since the Nasser regime (1954-1970) the state has been the largest employer of women.

The harassment of women became common in factories, streets, movie theaters, and on public transport. Although there are abundant police reports and court files on such incidents, harassment was not criminalized. The perpetrators faced charges only for misdemeanors linked to harassment, such as slander of policemen, defamation, or injury of a victim (Hammad 2016). Victims were mostly poor working-class women whom the Egyptian feminist movement, championed by upper- and middle-classes women, overlooked. The vibrant feminist movement in the interwar periods was very busy calling for female suffrage (Badran 1996).

As Baron rightly notes, nationalists used female honor to mobilize men against foreign control by gendering Egypt as a woman and men to protect the state in the same way as they would a female's virginity (Baron 2005, 40-42). Unfortunately, this 
sexualized image of the nation persisted, as did the exclusion of women from traditional political spheres (Baron 2005: 56). Obviously, bourgeois women were too polite to pay attention to sexual violence or harassment that they had never experienced. Aside from rape, women's safety in public spaces was never written into any Egyptian laws. The state's intensive attempts to control the expanding urban space did not provide women with legal protection against harassment. Successive penal codes (e.g., the 1883 Legal Code, the Native Penal Codes of 1904 and 1937) detailed violations of public morality (hurmat al-adab wa husn al-akhlaq) pertaining to public performances, particularly in theaters and the press, but none of these codes provided any specific protection to women against harassment in public spaces (al-Misri 1931). The state was too busy asserting its power and policing class boundaries, lower-class morality, and public order to guarantee women safety and gender equality in public spaces.

Women's presence in public spaces on their way to school and/or work is the condensed essence of the transformation Egypt underwent in the 20th century. Yet, women's access to the expanding public spaces continued without adequate legal protection, thus emboldening some men to make unwelcome advances in public. Anonymity in the crowded urban space may have provided restless men with a sense of being exempt from showing social courtesy in public. Harassing women from different socio-economic backgrounds in diverse public places in interwar Egypt, I argue, was an expression of rising gender and class tensions rather than the communication of sexual needs and desires. Harassment of women is not necessarily an expression of sexual deprivation or men misbehaving when they suddenly come across women in the street, workplace, and other public places. Before and throughout the 20th century lower-class men and women worked together in the field, marketplace, and other workplaces. Throughout the first half of the 20th century, lower-class women were sexually available to men in licensed prostitution quarters.

The harassment of women is, rather, an attempt, by disenfranchised or disaffected males who were at the bottom of the male power structure themselves, to impose casual male dominance. Very often women have passively endured licentious gazes, and incidents of sexual harassment, which were common, went undocumented. Victims might not have felt threatened enough by the perpetrators or preferred to keep a low profile and ignore the harassment. Such passivity made harassment almost a risk-free source of entertainment and guaranteed aggressive male sexuality in public spaces that were shared by men and women. Gradually, an unwritten code emerged, and perpetrators began to read any active protest or rebuttal by victims as encouragement to continue engaging in such behavior.

\subsection{State Feminism and the Preserve of Patriarchal Culture}

Ending the British occupation and introducing state welfarism, Nasser's regime adopted the feminist demands of suffrage and established the state-sponsored Egyptian Feminist Union. Nasser's regime was committed to gender equality in the workplace and in education, but ignored issues relating to the safety of the female body and sexuality (Hatem 1992). In sum, state feminism came with a price and did not lead to a cultural revolution. In theory, state feminism gave men and women from all classes equal opportunities in 
terms of education and work, making the state the largest employer. The state controlled civil society, making the feminist union a state instrument rather than allowing it have an independent role in expressing popular movements and demands. Egyptian feminists, like all trade and labor unions, followed the state agenda. Coopted or coerced, feminists under Nasser did not formulate an agenda for women's right and demands beyond what was suggested and permitted by the regime. More women became visible in public, while anxiety about potentially independent women intensified.

While Nasser's regime suppressed most oppositional forces, the pseudo-liberal film industry expressed great concern about societal changes through what I call the virginity industry. Flourishing commercial cinema was a key tool for turning virginity into a sacred ideal and imagining the ideal woman as a body without desire. Due to its popularity and ability to skip the limits imposed by illiteracy, Egyptian cinema has enjoyed very great importance as a discursive tool since the 1940s. Almost all the female stars in the 1950s and 1960s - such as Fatin Hamama, Magda, Su'ad Husni, and Shadyya - at least once portrayed of a reckless or naive girl who paid a high moral price for losing her virginity before marriage.

Ironically, today's Egyptian activists use examples of these stars as icons of Egyptian modernity in the face of Islamist conservatives. Films communicated a strong message that virginity is an unquestionable ideal across classes, thus emphasizing that a woman's body is her social capital and does not belong to that of a desire-less woman. State feminists were reluctant, unwilling, or unable to tread new paths and demand that women be autonomous. They never questioned the validity of virginity or demanded that the female body be protected from the brutality of female genital mutilation (FGM) or sexual harassment in public spaces.

One could argue that harassment was not as epidemic and as violent as in the last decade of the 20th century. Yet, the harassment of women in public, even at the level

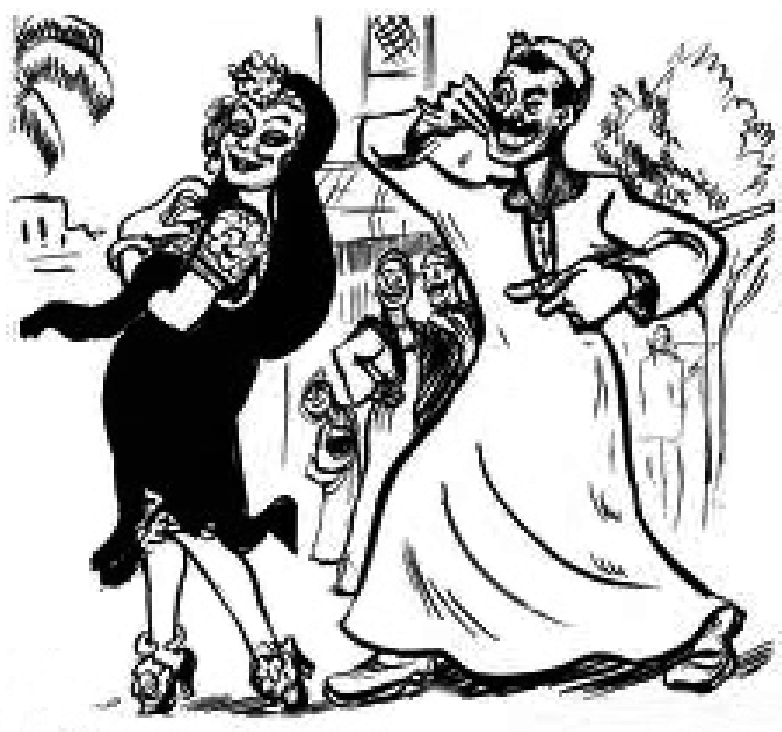

Fig. 2:

Caricature by Sarukhan showing a baladi woman happy to be flirted with. 
of gazes and verbal abuse, was alarming. Even more disturbing was the acceptance of these advances, and some writings even praised these practices as if they were good for women ('Umar 2014). The press at the time depicted sexual harassment as a source of amusement for women, as in caricatures Bint al-Balad by Sarukhan (Fig. 2). Sexual harassment became little more than a bad habit when it led to road accidents (Fig. 3). Warning that drivers staring full of lust at women might cause accidents speaks of the existence and spread of this form of harassment in the 1950s. Thus, sexual harassment was not unusual at a time when roads were less crowded and more orderly and when the state was championing a notion of gender equality.

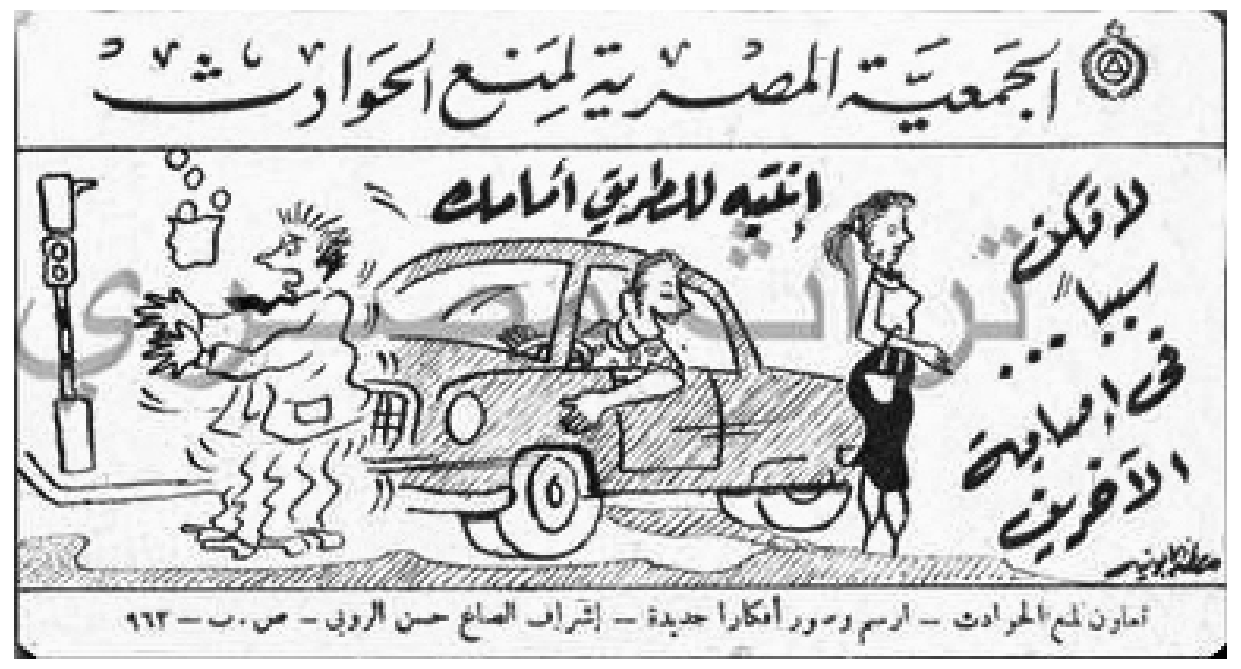

Fig. 3: Drawn by Mustafa Salih al-Abunayh.

"Look forward, don't cause other's injuries," sponsored by the Egyptian Society for the Prevention of Accidents, 1959.

\subsection{The Demise of State Feminism, the Rise of the Liberal Shackles}

After Nasser, President Anwar Sadat (1970-1981) reshuffled the state's socio-economic polices. His regime launched rapid economic liberation programs aimed at integrating the country into the global economy, at rapprochement with the West, and the state's withdrawal from social welfare. These state policies continued at greater speed under President Husni Mubarak (1981-2011), which is consistent with globalized neoliberal polices.

Regimes following Mubarak's fall after the January 25 Revolution continued liberation policies in their crude neoliberal forms. These policies have resulted in high inflation, high prices, higher unemployment, particularly among women, a wide gap between the rich and the poor, and tough times for the middle class (Hatem 1992). Women's bodies once again reflected socio-cultural anxieties about rapid changes. Due to overpopulation, reproductive health became a discursive field that gave men 
and women autonomy over their intimate life only to empower the state's policies of reducing birth rates. Ali's work on state-sponsored family planning shows the pervasive, high level of pressure put on women (Ali 2002). State programs encouraged women to think like individual decision-makers for their immediate families and national interests. Simultaneously, the state faced popular resentment over its withdrawal from public services, and blamed women. Both the Islamists' and state's discourses called for women to stop working because their work is unproductive and causes male unemployment, overcrowded public transport systems, leading to a decline in educational standards and crowded urban and rural spaces. Due to inflation and high prices, middleand working-class families needed two incomes. Thus, women continued working at an increasing rate in unfavorable milieus and under discourses that do not appreciate their work or presence in public.

Against that backdrop, veiling the female body, wearing the hijab, became a social and religious ideal, and since the late 1970s the hijab has steadily became an uninformative and normative dress code. Layla Ahmad discusses the veil's resurgence, claiming that covering a woman's body is not simply a response to the Islamist discourses about modesty fulfilling religious dictates (Ahmed 2014). For many women since the late 1970s turning to the hijab represented a compromise between moving forward into education and work on the one hand and preserving a sense of privacy and protection on the other. Women coated their hijab practice in religiosity and authenticity, and social expectations of fending off the unwelcome male gaze and verbal and touch abuses. Put simply, anti-women discourses have burdened women with the false notion that leaving their homes to engage in work or education is a privilege and that being in public is wrong. Women had to compromise; they covered more of their bodies and ignored harassment lest they face the question of "Why are you outside the home?"

This brutal ideological repression typifies the aberrant behavior toward women. Facing harmful harassment, women who feel violated or intimidated by "typical" male behavior have no way of specifying how or why typical male behavior feels like aberrant behavior. Women face verbal or physical violence in public, while they are unable to recognize it and society does not criminalize it (Kelly 2002: 132).

\section{The 1990s and Beyond: State Brutality and Neoliberalism}

Given the fear of attracting negative attention and the lack of legal protection, safety in public, and social support, individual women have adopted different tactics to protect themselves. In crowded buses, women stand back to back and make their bodies as small as possible, hoping to become invisible. Individual women have to stand at an angle to minimize how much of their body is open to being rubbing up against by harassers. If a woman manages to cadge a seat, she puts something like a book or a purse between herself and a seated male to stop him pushing his body up against hers. Women walking in crowded streets have to make a tough choice between facing pedestrian harassers on crowded broken sidewalks, or they risk walking down the middle of the road between cars whose drivers could also harass them. Crowded spaces create unwelcome closeness 
and deprive individuals of their right to privacy and safety. Anger, aggression, and harassment are more common in crowded places (Mahmud 2013). Whenever possible, women seek male companionship, for example that of a brother, husband, or male friend, or avoid leaving the house altogether. Women's pacifism has contributed to a collective state of denial and societal silence. Silence and the legal vacuum constituted ideological coercion to continue the reproduction of the patriarchy in the age of female labor. Over the last two decades, harassment has become epidemic in Egyptian streets, both urban and rural.

In the absence of the offence of sexual harassment, we do not have any reliable statistics relating to this practice. The relatively active civil society under Mubarak started to pay attention to the issue against the backdrop of international discussions of sexual harassment as a form of gender-based violence. In 1993, the UN Committee on the Elimination of Discrimination against Women (CEDAW) included sexual harassment in its definition of gender-based violence against women. In preparation for the UN Conference in Beijing, two Egyptian NGOs, the New Woman Research Foundation and El Nadim Center for the Management and Rehabilitation of Victims of Violence, carried out field research in 1994 into women's perceptions of gender violence. The majority of women ( 94 percent) had heard of women being harassed in the street and 64 percent had experienced it themselves. A total of 52 percent of the women recognized that women are likely to be harassed in the workplace and 12 percent themselves had experienced it (NWRF \& El Nadim n.d., 5-6).

A more recent survey of 2020 male and female participants revealed that 83 percent of Egyptian women and 93 percent of foreign women have experienced sexual harassment in Greater Cairo (Hassan and Shukri, 2008). Most of the surveyed women experience harassment on a daily basis, with verbal abuse being the most frequent form of harassment. Touching parts of a woman's body and exposing victims to men's genitals are not uncommon. Sixty-two percent of the surveyed men acknowledged they committed different forms of sexual harassment on a regular basis, mostly verbal abuse and staring. Some of the surveyed men admitted attempting to touch women's bodies and exposing their sexual organs. Interestingly, only 41.8 percent confirmed that they committed sexual harassment to satisfy sexual desires. More shockingly, 23.1 percent admitted they did it to impose their masculine dominance and to humiliate women, and 19.3 percent confirmed that they practice sexual harassment not for any particular desire but because it has been a habit since they were young (Muhammad 2008).

The UN Women study published in 2013 reported that 96.5 percent of surveyed women had been physically molested - touched, grabbed, or groped - by men in a public place, in addition to having been verbally harassed. The study found that the main areas in which sexual harassment takes place are the street ( 89.3 percent) and public transport (81.8 percent) (FIDH, Nazra for Feminist Studies, New Women Foundation and Uprising of Women in the Arab World 2014: 19-20). Women have faced daily sexual harassment in the streets, public transport, shops, markets, schools, universities, clubs, tourist spots, protests, and in the workplace. The El Nadim Center documented 64 cases of sexual assault that took place in police stations in one year (El Nadim, 2004 and 2014). Yet, most cases go unreported.

All the above studies confirm that sexual harassment has serious consequences for women's freedom of movement, including the use of public transport, going out on 
public holidays, walking in the streets after dark, or going out at all (FIDH, Nazra for Feminist Studies, New Women Foundation and Uprising of Women in the Arab World 2014).

Sexual harassment has also claimed women's lives. For example, one man sexually assaulted Iman Salama in the street in Assiut in September 2012. When she spat at the perpetrator, he shot and killed her. Shuruq al-Turabi was run over by a car in August 2013 in Tanta after she objected to harassment by the driver. These two cases are evidence of how widespread sexual violence against women is and to what extent women have become afraid of Egyptian streets, both in Cairo and in the provinces, in rural and urban areas.

\section{The Age of Gang Sexual Assault}

Ten years ago images of violent mob harassment shocked the Egyptian public and the state despite initial denials that it was taking place. The first documented incident took place during anti-Mubarak's protests in 2005 when several female protesters faced collective sexual assault in downtown Cairo. Many believe that the thugs who committed the incident - known as Black Wednesday - had links to state security personnel in plain clothing. The state denied the reports and rejected all calls to investigate even an assault that took place outside the Press Syndicate under the eyes of state security generals. Survivors identified the faces and names of security officials who had attacked them and distributed their pictures in the form of wanted posters.

These incidents became highly politicized in public debates for obvious reasons: police security might have orchestrated the attacks to deter protests. The state's failure to protect women from the regime's thugs inspired activists to document the frequency of mob sexual assaults. The blogger and activist Wael Abbas posted clips of gang assaults against women on three important occasions: in downtown Cairo during the Eid holidays (the religious holiday that follows the end of Ramadan), during the African Cup in Cairo Stadium in 2006, and in Fayum Province during the Shamm El-Nasim holiday (the ancient Egyptian celebration of spring) in April 2007. Independent TV talk shows and the press discussed what was termed su 'arr jinsi, sexual rabies or sexual frenzy. Security personnel denied the incidents, while sociologists and media commentators cautiously acknowledged that it had happened, claiming it was a recent phenomenon and doubting that it was widespread. ${ }^{2}$ Over the last few years, mob sexual assault has become a repeated pattern in crowded streets, particularly during public holidays and political protests. In some incidents in Tahrir Square, assaulters used knives to slash victims' clothing and flesh. Some reports revealed that survivors' vaginas had been penetrated using sharp tools. All witnesses of such incidents agree that most males in gang assaults are teenagers, some of them as young as ten years old and few above 23 years old.

In the period between October 2012 and March 2013, Harassmap, a smart-phone application launched in 2009 that allows incidents to be reported and tracked on sight, received 269 reports of sexual harassment, with 46 percent of perpetrators under 18

2 www.youtube.com/watch?v=eJk-Ue6XaVE\&spfreload=10; www.youtube.com/watch?v=Uq0OHH UqzbU\&spfreload=10; www.youtube.com/watch?v=9nLJJHt-L6k. (Last access 2 February 2017). 
years old. Fifty-three percent of reports were classed as violent physical sexual assault. Sixty-three percent of cases took place in the street, 6 percent in public transport and 6 percent in educational institutions. According to the Egyptian Center for Women Research (ECWR) survey of 2008, the majority of those responsible for sexual harassment and assaults in the streets are between 12 and 17 years old. Many of those interviewed reported increasing numbers of even younger boys harassing women and girls in the street, usually in the form of verbal harassment or groping: "It's like a game, young boys bet on who will get to a woman first. Her body is a game." (FIDH, Nazra for Feminist Studies, New Women Foundation and Uprising of Women in the Arab World 2014: 22.).

Why is sexual harassment so persistent and why has it taken on a more violent and collective form over the last two decades? What makes teens and boys as young as ten and twelve years old engage in these acts of sexual violence and aggression? Although witnesses in many cases describe harassers as coming from slums and informal housing ('Ashwa'iyat), middle- and upper-class men driving fancy cars also harass women. We need to ask more questions about how gender functions in the lives of young men implicated in sexual violence of the kind that has been experienced in public spaces in Egypt.

Some harassers are married men and some are too young to be thinking of sexual favors. About half of the perpetuators denied they do so to seek sexual satisfaction; instead, they do it out of habit and to show masculine dominance, as already mentioned above. Harassment is a way of proving one's masculinity and achieving self-esteem under a political dictatorship that emasculates men and socio-economic contexts that deprive the majority of the population of another way of engaging in good moral behavior and having self-respect (Amar 2011). Instrumental explanations in Marxist scholarship attribute sexual violence against women to class conflict or, in liberal and cultural approaches, to the collapse of democratic and religious values (Devji 2013; Mahmud 2013; Mahfuz 2008).

Although it might be possible to rationalize some violence, some is beyond any rational or instrumental purpose. Employing the concept of intersectionality developed by feminist studies, the theory of the victimization of women could help us to better understand the masculine gender.

We should discuss the masculine gender at the intersection between class structure and social culture that is informed by neoliberal economy and state security policies in contemporary Egypt. Harassment must be situated in everyday life in the context of wider developments in Egypt since the demise of state-led social welfare under Sadat's regime (1970-1981), the shift to neoliberal policies, and the deepening of the security state under Mubarak and successive regimes after the Tahrir Uprising of 2011 until the present. I also suggest theorizing sexual harassment, a form of gender-based violence, in the light of the continuum of violence from the ruling regime to control the population and contain dissidents to public violence of humiliated males to ensure dominance (Cockburn 2004). I am not suggesting a mechanical trickling of violence from the center/state down to men and from men to women. I attempt to address the connections between the regime's violence that humiliates men and women, patriarchal culture that idealizes male dominance, and the creation of a violent milieu that victimizes the weak: the poor and women. We need to observe the functioning of gender as a relation, and a relation of power, that compounds other power dynamics (Cockburn 2004: 25). 
When a regime violently monopolizes masculine superiority through the tactics of fear against a cultural backdrop that celebrates masculinity and degrades femininity, men find in women a target for their violence. Under political regimes that made physical torture and raping males in detention centers and police stations gruelingly fearsome, men pick up the shattered pieces of their sense of manhood at the expense of women. Taking a gender perspective on the successive moments in the flux of political repression in ordinary everyday governance reveals features of internal societal and state-society conflicts, which I label a continuum of violence. Crowded public spaces with no substantial services to make them safe for all citizens are perfect for men to apply their masculine dominance to the extreme hyper-masculine aggression. Yet, harassers, rapists, and sexual assailants may and may not represent one end of a quasi-social continuum of male sexual aggression (Kelly 2002). The concept of the continuum of sexual violence draws attention to a wider range of forms of abuse and assault that men and women experience and that are committed by different actors, from the state to the individuals. Thus, the continuum of violence might illustrate the links between everyday abuse by the state and male abuse. An inefficient and corrupt state feeds into an abusive gender order.

Violence was the main tool in the state's response to Islamist activism in the 1990s, and by the time Islamist violence faded away in the late 1990s, more strategies of state control were put into effect. The state has normalized emergency laws by enshrining them in the law on combating terrorism and the law on thuggery of 1998, as well as by expanding surveillance and monitoring campaigns. These laws and surveillance systems have targeted young men, particularly lower-class and unemployed men. Thus, young men's everyday encounters with the state disrupt the dominant masculine construct. These encounters put young men in opposition to the state. We need to take this disruption into account to understand the renegotiation of gender relations in the family and in public (Ismail 2006). While the state's heavy security has been relatively successful in cracking down on Islamist associations, the state has failed to provide social security to the social groups that fed Islamists movements. The state's withdrawal from social welfare has meant, among many things, the decline in education and the disappearance of public spaces for young men to use as popular sport institutes (sahat sha 'biyya). Meanwhile, leaving one's neighborhood alone might bring young men under security state surveillance, and possibly bring about police violence. Large numbers of young men live in areas where there are no clubs, no parks, no sports halls, no good education, and no confidence in their own success and mobility through effective education, talent, or hard work. The only capital some males feel they have is being a man, thus being superior to nameless women in both the public and private spheres.

The advancement of neoliberal policies in the late 1990s, overpopulation, and rapid urbanization caused increasingly crowded public space, inhabited by individuals who did not know or relate to one another. Thus, it is not necessary to treat others courteously. The deterioration in state services created competition among the population, particularly among the lower classes, over access to public spaces. Streets and public transport are morally and materially broken, which has inhibited courtesy and encouraged aggressive competition in an unruly and uncivil game. Egypt's large annual budget for internal security, around $\$ 1.5$ billion a year, exceeded the entire annual government budget for 
healthcare in 2006. Yet, police work has mostly focused on securing the regime (Bowker 2010). Egypt's population doubled between the 1980s and 2000s, making the under 30 age group the largest. The state is no longer providing services, thus the population, mostly the young, have to engage in unruly games to provide for themselves and grab whatever is possible. The state, as a web of institutes, individuals, and rules, is becoming too weak to apply the law consistently to everybody and too corrupt to treat everyone equally. Everyone's agenda, namely to enjoy access to spaces and resources, is clear, but there are no rules as to how to achieve that and how to avoid encountering the violent state's apparatus. Everyone wants to get as much as possible, yet no one knows what is possible and how much is enough. There are no restrictions or rules except whatever you can get away with. Crowded public spaces are becoming increasingly disorderly, unruly, and unable to accommodate people's needs. Lack of security is part of a wide range of public services that are lacking and that has crucially contributed to the spread of societal violence, violence against the weak, against women in many forms, including sexual harassment.

While lack of social services deprives young men and women of spaces of sociability, political repression deprives them of political sociability and participation. Appropriating street corners and investing them as safe and familiar spaces, young men produce a territorialized identity of spatial bonding and belonging. Slums and neighborhoods become the only place where young men live, work, and spend time roaming alleys or aimlessly loitering in corners. Harassment, rather than friendship, becomes a "game" for entertaining, for demarcating territory, and for performing masculine dominance. Violence against women as expressed in gang sexual harassment becomes male groups performing masculine dominance that is tolerated by the state.

Eyewitnesses of gang sexual harassment during public holidays and demonstrations confirm that the police rarely attempted to protect women, although violent assaults were anticipated. In one incident on Eid el-Fitr in 2006, groups of men stripped women passers-by of their clothes in downtown Cairo. In 2008 on Eid el-Adha, groups of young boys committed a similar assault in Jami'at al-Diwal al-'Arabiyya, one of the major commercial and tourist districts in Cairo and Giza. The latter gang assault happened with a total absence of security, although the assault was expected. The police SOS hotline did not answer until a bystander, a journalist with connections, managed to call top officials in the Ministry of Interior Affairs and reported the assault. ${ }^{3}$

Gang assault - gang rape according to the testimonies of some survivors - might lead us to understand specific forms of bonding between men and between boys and older men. Loose fraternities in informal slums and neighborhoods play a role in shaping masculine identity and young men's social engagement. Based on observations in the late 1990s, Ismail has argued that this role manifested in membership of different Islamic organizations and religious music bands as well as fraternal relations that developed in workshops and in neighborhoods (Ismail 2006: 98). These associations and social groups contribute to a sense of solidarity and to the building of social networks beyond the family. Work relations, spaces of sociability, and patterns of spatial mobility reinforce an identity that is quarter-based and linked to a particular lifestyle and to a particular set of social norms. Against this background we can understand the construction of masculinity,

www.youtube.com/watch?v=E6cJwhV54T8. (Last access 2 February 2017). 
gender relations, and interaction with the state (Ismail 2006: 98). By virtue of their age, their class position and their experience of subordination, young men locate themselves in the power hierarchy through constructions of masculinity that not only express their marginalized position (Ismail 2006: 96) but seek to reproduce hegemonic masculinity.

The male phrase "Don't you have a brother like me?" is the reverse of the maxim that women used to stop harassers by reminding them that they could be their sister and deserve respect and protection. Turning harassment into a joke by no means expressed social confidence in public spaces that are free from the plague of harassment. It also shows that the females' plea for a sense of affinity and respectability from males has lost its effectiveness. Harassment steadily spread across social and geographical locations, across classes, ages, and urban and rural areas. Against the backdrop of society's silence and women's fear, the practice has become normalized and ingrained in the social notion of masculinity and femininity. To be "masculine" is to be a harasser; to be "feminine" is to be a silent victim of harassment.

A ten-year-old or a teenage boy vulgarly and violently touching a woman he does not know in the street is neither an expression of sexual desire nor of a need for a tender touch. It is a cherishing of the social construct of masculinity in its absurd form in the knowledge that there will be no consequences. It is a masculine gender performance in the same way as the social notion of masculinity associates manhood with violence while tolerating, even encouraging, the degradation and subjugation of women. Performing aggressive hyper-masculinity with no purpose other than to assert predatory behavior is risk-free entertainment, a way to channel male sociopolitical frustration, adapt the abusive regime of the state-citizen relationship to the personal level where the oppressed and humiliated masculine fantasizes as the oppressor and fetishes the female body as a battleground that has been conquered.

With gang assaults during public holidays and the politically motivated harassment under the eyes of the security forces during the protests in 2005 and since 2011, the continuum of violence has reached an unprecedented peak. During the mass demonstrations under presidents Muhammad Mursi (2012-13) and Abd al-Fattah al-Sisi (the de facto ruler of Egypt since July 2013) arrested women activists were systematically subjected to "virginity tests" in 2011 by the army, to rape and sexual assault by mobs. Survivors and eyewitnesses reported the same pattern: tens of men surrounded victims, tore off their clothes and groped their bodies. Some suffered multiple rapes by perpetrators who were often armed with sticks, blades, and other weapons.

There were also reports of the sexual assault of women protesters by the police and security forces during the violent dispersals of sit-ins and protests in Cairo in August and November 2013. Between 3 and 7 July 2013, more than 85 cases of sexual assault, including several cases of rape, were perpetrated by mobs in and around Tahrir Square. Coincidentally, a mob attack against women protesters in Tahrir was aired live on television, as cameras were filming a demonstration on 25 January 2014. These assaults exposed the failure of the patriarchy as usual (Kandiyoti 2014). Whether employed by the state or encouraged by the state's failure to keep women safe, activists put sexual harassment right at the top of their agenda. The security forces failed to intervene to protect female protesters, prompting citizen's movements to set up their own security patrols and bodyguard corps (FIDH, Nazra for Feminist Studies, New Women Founda- 
tion and Uprising of Women in the Arab World 2014: 3). Sixteen Egyptian NGOs and movements launched the Taskforce Combating Sexual Violence. The spectrum of antiviolence has registered substantial success.

\section{$5 \quad$ The Rising Revolutionary Order}

Sexual harassment has emerged as a highly politicized issue rather than a tenacious social vice. The celebrations of the initial success of toppling Husni Mubarak in February 2011 reveal that revolutionaries understood sexual violence as a part of the continuum of violence. Egyptians exchanged congratulatory messages promising each other a future Egypt devoid of sexual harassment and streets full of trash. More work was needed as the revolution itself went through its ups and downs that eventually led to the current dictatorship. Activists developed initiatives to trace and document abuse and to help survivors. Publicizing filmed incidents and testimonies from survivors and eyewitnesses successfully challenged the social denial, disgraced societal acceptance, and the state's complicity. Breaking the silence started with the courageous Nuha Rushdi who pressed charges against the driver who groped her in 2008, but it took more heroic steps by women like Yasmin el-Baramawi and others to talk on TV and other media about their experiences of gang assault and rape during the protests in al-Tahrir.

Breaking the silence has encouraged more survivors to speak up and face society with gruesome reality and has encouraged more women to defend themselves, thus changing the mainstream attitude of victim blaming (Elhameed 2016). According to Harassmap, in recent years the number of documented cases has increased, although that does not necessarily reflect an increase in the number of crimes being committed, but it certainly speaks of a great shift in the way people have looked at the issue since 2005/06, when no-one would speak about it. During a first public campaign to break the silence about the epidemic of harassment people scratched the words "sexual harassment" off stickers put up in the streets. Reports on Harassmap disgraced bystanders who passively watched sexual harassment as if it were a "TV show." Sharing their experiences allowed women to help each other in recognizing violations against them even when they were "only" verbal.

There has been unprecedented media coverage of the issue that goes beyond breaking the silence to bring about a change in public attitudes. All the debates label sexual harassment as a shameful and harmful act, not as typical, accepted behavior; the victim has nothing to be ashamed about. Changes in public attitudes appeared when people put the president of Cairo University, Gabir Nassar, under pressure to apologize for a statement in which he blamed a case of collective sexual harassment on campus in March 2015 on "the victims' indecent dress." He led a student demonstration against sexual harassment in November 2015. More recently, in July 2016 the al-Masri alYum daily newspaper had to withdraw and apologize for a cartoon degrading harassed women. ${ }^{4}$ The apology came a few hours after an intensive social media campaign was launched against the cartoon.

4 www.almasryalyoum.com/news/details/976525. (Last access 2 February 2017). 
Cellphone cameras and apps that make documentation easy have put more pressure on policemen to report incidents lest victims disgrace the police with pictures and clips on social media. Activists are reporting a dramatic change compared to recent years when policemen declined to fill out harassment reports. With police cooperation, it has become common for harassers to be convicted in court. The change has also touched most state institutions, which have enlisted universities and cultural centers to host events on combating harassment. For example, 'Ayn Shams University established a unit for that purpose last April and the Egyptian Opera House hosted a photograph exhibit entitled "No to Harassment" in May 2016. We can appreciate the change if we note that three years ago the Human Right Committee in the Shura Council, the only chamber in parliament at the time, blamed rape and harassment on the victims who chose to participate in public protests (Gharib 2013).

Arguably, legal changes have been one of the most important successes of ongoing anti-harassment activism (Kirollos 2016). In January 2014, Egypt adopted a new constitution that contains, for the first time, a provision on combating violence against women. Urgent measures are required to ensure that it does not remain just words on paper. In June 2014, an amendment to the Egyptian Penal Code saw the introduction of harassment as a crime. Since then, the Ministry of Interior Affairs has established a special department to handle cases related to sexual harassment and anti-women violence in each security headquarters. These departments have expedited investigations and put perpetrators on trial.

These changes have encouraged more women to report incidents against them. Previously, victims avoided pressing charges because they did not want to equate being harassed and molested with being raped. The chance that perpetrators will be punished on the basis of the new law is much higher than when judges had to apply articles on rape, i.e. penetrating female genitalia. The legal amendment has been particularly effective in combating the crime. According to official reports, there were 661 sexual harassmentrelated cases in 2015 (al-Badri 2015). An independent think tank has reported that 2259 individuals were arrested in 2015 on harassment-related charges (Ahwal 2015).

Work done by NGOs, citizen initiatives, and individual and group feminists since 2005 has shattered taboos about sexual harassment (FIDH, Nazra for Feminist Studies, New Women Foundation and Uprising of Women in the Arab World 2014: 20). In addition to women activists, a good number of men work in anti-sexual harassment initiatives such as Shuft Taharush (I Witnessed Harassment) and Imsik Mutaharish (Catch the Harasser). It is not uncommon for men to have championed feminism in Egypt since its inception in the late 19th century. Yet the current involvement of males in anti-harassment campaigns marks a new generation of male activists who are able to take a fresh perspective on gender issues. They are engaged directly and on a regular basis in conversations with female colleagues about protecting a woman's right to control her own body and sexuality. ${ }^{5}$ This is a radical departure from a tradition in which male and female intellectuals and activists conversed mostly indirectly through the press. The ongoing coed activism and discourse involves an unprecedented critique of the patriarchal sexual regime. Interactions between male and female activists are creating a new milieu that is opening up new horizons for Egyptian feminism and social values. With the participation of male and female activists,

$5 \quad$ I am grateful to the activist Dalia Abd Elhameed who illuminated this point during our conversations. 
Fig. 4: "No to Harassment", graffiti by Mirah Shihadeh on a Cairo street wall.

some initiatives have dropped the long-standing tradition that protecting women is a man's responsibility. Slogans urging men to "protect her" have been dropped and have given way to slogans such as "The street is for me and you", "Safe public spaces for all" and "Protect yourself" (see Fig. 4).

The development in activism around gender and sexuality in general and violence against women

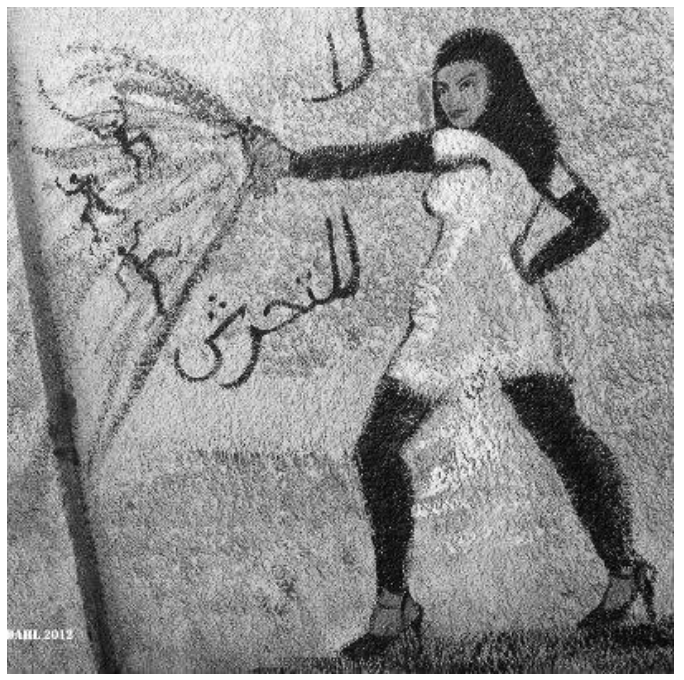
and sexual harassment in particular in the wake of the Tahrir Uprising is a good example of the revolutionary continuum: Bread, Freedom, Social Justice and Human Dignity. Like many activists around the globe, individuals from the post-materialist generation from different socio-economic backgrounds and ideological stands discuss in public and private settings their position against the continuum of violence of global neoliberalism and local authoritarianism (Arat 2013). Since the massive protests in 2011, resistant movements have continued to endorse more cosmopolitan and universal concepts of justice, including women's and gender issues. This does not mean an absolute discursive or real victory, as some counter-activism also uses social media and street stickers that hold women responsible for sexual harassment on account of their "bad" demeanor and revealing clothing. ${ }^{6}$

\section{Conclusion}

Many have seen the ongoing developments in Egypt since the Tahrir Uprising of 2011 as a struggle between democratic forces and dictatorship, social justice and neo-liberal policies, and between pluralism and the marginalization of dissidents and minorities.

So far, the outcome of these struggles has not been favorable. Anthropologist Jessica Winegar began analyzing the level of depression and frustration among Egyptians as early as 2013 (Winegar 2013). Historian Joel Benien casts doubts about whether what happened in Egypt in early 2011 was a revolution, even if it felt like one (De Smet 2014: 11). On the second anniversary of the Tahrir Revolution, Beinin wrote that what happened in January 2011 "is not over, rather it has not yet occurred" (De Smet 2014: 11).

6 مير ابك شم https://www.facebook.com/search/top/?q=\%D9\%84\%D8\%A7\%D8\%A8\%D8\%B3\% D8\%A9\%20\%D9\%85\%D8\%AD\%D8\%B2\%D9\%82\%20\%D9\%84\%D9\%8A\%D9\%87\%20 \%D8\%A7\%D9\%84\%D8\%B4\%D8\%A7\%D8\%B1\%D8\%B9\%20\%D9\%85\%D8\%B4\%20\%D9\%83\%D8\%A8\%D8\%A7\%D8\%B1\%D9\%8A\%D9\%87\%20. (Accessed 2 Februar 2017.) 
Despite the popular uprising, the state apparatus has remained largely intact with no fundamental changes occurring in the political or economic relations of power. Despite toppling former president Husni Mubarak, the regime's socio-economic structure has been preserved. All these views could be valid and the outcomes of the uprising could be anything but radically transformative. In a close examination of the transformation pertaining to the female body as a site where all these ongoing struggles and contradictions are taking place, I argue that Egyptian women have registered revolutionary progress that has charted their path to controlling their bodies. While patriarchy went too far in its assault on the female body when neoliberal policies and the security state intensified the continuum of violence, the revolutionary forces have succeeded in putting forth a new national agenda toward women's control over their body and sexuality. Women have succeeded in destabilizing the traditional order that had excused and legitimatized different violations against the female body. In the new order, women succeeded in criminalizing sexual harassment against them, a plague that has been endemic in Egyptian society. Activists have succeeded in banning the virginity screening of female detainees and prisoners, getting the state's hand off a woman's body. When the public grew more sympathetic toward the victims of virginity screening, a woman's privacy became a more important ideal than virginity. Activists have done valuable work in combating and criminalizing FGM, another important issue that goes beyond the scope of this article. Egyptian society is still far from being progressive in a broad sense. With the continuation of the security state, political repression, and a lack of state-sponsored social welfare, there is plenty of work to be done to preserve recent achievements, not to mention to increase them and move forward.

\section{References}

Ahmed, Leila (2014). A Quiet Revolution: The Veil's Resurgence, from the Middle East to America. New Haven: Yale University Press.

Ahwal, Daftar (2015). Hamalat al-qabd ala khalfiyyat al-taharush $f i$ Misr mundhu isdar qanun al-taharush al-jinsi hatta 30 September 2015 [Arrest campaigns against harassers in Egypt since the issuance of the sexual harassment act until 30 September 2015]. Cairo: Daftar Ahwal.

al-Badri, Yousri (2015). "Dabt 3163 qadiyya fi majal mukafahat jara'im al-adab khilal 2015" [Reporting 3163 cases pertaining fighting against morality crimes during 2015]. al-Masri al-Yum, 28 December 2015.

Ali, Kamran Asdar ( 2002). Planning the Family in Egypt: New Bodies, New Selves. Austin: University of Texas Press.

al-Manfaluti, Mustafa Lufti (1984). Mu'alafat Mustafa Lutfi al-Manfaluti al-Kamila [The complete writings of Mustafa Lutfi al-Manfaluti]. Beirut: Dar al-Jil.

al-Misri, K. (1931). Qanun al- 'Uqubat al-Ahli Mudhayyal bi-Ahkam al-Mahakim al-Ahliyya liGhatyat 1930 [The local penal code followed by verdicts of the local court until 1930] . Cairo: al-Maktabat al-Tujariyyat al-Kubra.

al-Muqattam, August 19, 1898.

al-Mu'ayyid, October 30, 1906 and January 8, 1908.

al-Nadim, Abdullah (1892a). "al-Taqlid yanqil tiba" al-muqallad" [Imitation transmits the traditions of the imitated]. al-Ustadh, 61-63. 
al-Nadim, Abdullah (1892b). "al-Rawi" [The story teller]. al-Ustadh, 145-147.

al-Nadim, Abdullah (1892). 'Madrasat al-banat: Sharifa and Bahiyya' [Girls' School: Sharifa and Bahiyya]. al-Ustadh 1: 17, 395-9.

Amar, Paul (2011). Middle East Masculinity Studies: Discourses of 'Men in Crisis' Industries of Gender in Revolution. Journal of Middle East Women's Studies, 7(3), 36-70. https://doi. org/10.2979/jmiddeastwomstud.7.3.36

Arat, Yeşim (2013). Violence, Resistance, and Gezi Park. IJMES 45, 809. https://doi.org/10.1017/ s0020743813000962

Badran, Margot (1996). Feminists, Islam, and Nation: Gender and the Making of Modern Egypt. Princeton: Princeton University Press. https://doi.org/10.1515/9781400821433

Baron, Beth (2005). Egypt as a Woman: Nationalism, Gender, and Politics. Berkeley: University of California Press.

Bowker, Robert (2010). Egypt and the Politics of Change in the Arab Middle East. Northampton/ MA: Edward Elgar Publishing. https://doi.org/10.4337/9781849805124

Cockburn, Cynthia (2004). Continuum of Violence: A Gender Perspective on War and Peace. In Wenona Giles \& Jennifer Hyndman, Sites of Violence: Gender and Conflict Zones (pp. 24-43). Berkeley: University of California Press.

De Smet, Brecht (2014). Revolution and Counter-revolution in Egypt. Science \& Society, 11-40. https://doi.org/10.1521/siso.2014.78.1.11

Devji, Faisal (2013). Communities of Violence. IJMES 45, 801. https://doi.org/10.1017/ s0020743813000949

Elhameed, Dalia Abd (2016). For the Women of Egypt, Today is Not Like Yesterday. Mada Masr, March 8. Date of access: 2 February 2017 at www.madamasr.com/en/2016/03/08/opinion/ society/for-the-women-of-egypt-today-is-not-like-yesterday/.

El Nadim. (2004). Shahadat al-nisa' 'ala al- 'unf dakhil amakin al-ihtijaz [Women's testemonies pretaining violence in detention stations]. Cairo: Markaz el-Nadim lil-'ilaj wa al-ta'hil alnafsi.

El Nadim. (2014). Qira'a fi malaffat birnamij al-nisa' al-mu 'annafat [A reading in the files of abused women's program]. Cairo: Markaz el-Nadim lil-'ilaj wa al-ta'hil al-nafsi.

FIDH, Nazra for Feminist Studies, New Women Foundation and Uprising of Women in the Arab World (2014). Keeping Women Out: Sexual Violence Against Women in The Public Sphere. Date of access: 2 February 2017 at www.fidh.org/IMG/pdf/egypt_sexual_violence_ukwebfinal.pdf.

Gharib, M. (2013). Huquq al-insan bilshura: al-fatah al-musharika fi al-muzaharat tusshim fi ightisabiha $100 \%$ [Human Rights in Shura Council: The woman who participates in demonstrations is responsible for their rape 100\%]. al-Masri al-Yum, 11 February.

Hammad, Hanan (2014). Regulating Sexuality: The Colonial-National Struggle over Prostitution after the British Invasion of Egypt. In Marilyn Booth \& Anthony Gorman, The Long 1890s in Egypt: Colonial Quiescence, Subterranean Resistance (pp. 195-221). Edinburgh: University of Edinburgh Press. https://doi.org/10.3366/edinburgh/9780748670123.003.0008

Hammad, Hanan (2016). Industrial Sexuality: Gender, Urbanization, and Social Transformation in Egypt. Austin: University of Texas Press.

Hassan, Rasha Muhammad \& Shukri, Alya' (2008). Ghuyum fi sama' Misr: al-Taharrush al-jinsi min al-mu 'akasat al-kalamiyya hatta al-ightisab, dirasa sociologia [Clouds in Egypt's Sky: Sexual harassment from verbal molestation to rape, a sociological study]. Cairo: Egyptian Center for Women's Rights.

Hatem, Mervat F. (1992). Economic and Political Liberation in Egypt and the Demise of State Feminism. International Journal of Middle East Studies, 24(2), 231-251. https://doi. org/10.1017/S0020743800021541 
Ismail, Salwa (2006). Political Life in Cairo's New Quarters: Encountering the Everyday State. Minneapolis: University of Minnesota Press.

'Itman, N. A. (1995). Tarikh al-sahafa al-Sakandariyya: 1873-1899. [The history of Alexandrine Press: 1873-1899] Cairo: al-Hayya al-Missriayya al-'amma lil-kitab.

Kandiyoti, Deniz (2014). Contesting Patriarchy as Governance: Lessons from Youth-led Activism. Date of access: 2 February 2017 at www.opendemocracy.net/5050/deniz-kandiyoti/ contesting-patriarchy-as-governance-lessons-from-youth-led-activism.

Kelly, Liz (2002). The Continuum of Sexual Violence. In Ken Plummer, Sexualities. Critical Concepts in Sociology. Some Elements for an account of the social organisation of sexualities (pp. 127-139). London, New York: Routledge.

Kirollos, Mariam (2016). The Daughters of Egypt are a Red Line: The Impact of Sexual Harassment on Egypt's Legal Culture. Kohl: A Journal for Body and Gender Research, 50-70.

Kozma, Liat (2011). Policing Egyptian Women: Sex, Law, and Medicine in Khedival Egypt. Syracuse: Syracuse University Press.

Mahfuz, D. a.-S. (2008). al-Taharush al-jinsi zahira bila watan [Sexual harassment a phenomenon without borders]. Date of access: 2 February 2017 at www.swissinfo.ch/ara/detail/index. html?cid=7019730.

Mahmud, S. S. (2013). al-Taharush al-jinsi fi Misr wa tahlil al-khubara' lil-qadiyya ka 'unf did al-mara' $a$ [The issue of sexual harassment in Egypt and the experts' analysis of it as violence against women]. Cairo: Egyptian Center for Women's Rights.

Muhammad Hassan, Rasha (2008). Clouds in Egypt's Sky: Sexual Harassment from Verbal Harassment to Rape, a Sociological Study. Cairo: Egyptian Center for Women's Rights.

NWRF \& El Nadim (n.d.). Once again... Women speak out. Results of a Field Research on violence against women in Egypt. Cairo: New Woman Research Foundation together with El Nadim Center.

Rida, Muhammad Rashid (1900). al-Tahatuk fi Misr wa talafih" [Sexual obscenity and how to fight it]. Al-Manar, September 25.

'Umar, M. (2014). Mutaharish wa aftakhir [I'm A Proudly Harrasser]. Akhbar al-Yum.

Winegar, Jessica (2013). Weighed Down: The Politics of Frustration in Egypt. MERIP, Middle East Research and Information Project.

\section{Author's details}

Hanan Hammad, Associate Professor of History and the Director of the Middle East Studies Program at Texas Christian University.

E-mail: h.hammad@tcu.edu 